\title{
Especial
}

\section{TENTANDO DEFINIR A ESTÉTICA \\ NEGRA EM DANÇA}

\author{
TRYING TO SET THE BLACK \\ BEAUTY IN DANCE
}

EL INTENTO DE DEFINIR LA ESTÉTICA DE LA DANZA NEGRA

\section{Nadir Nóbrega Oliveira}

Nadir Nóbrega Oliveira PhD em Artes Cênicas - Dança pelo Programa de Pós-Graduação em Artes Cênicas da

Universidade Federal da Bahia. Professora Adjunta do Curso de Licenciatura em Dança da Universidade Federal de Alagoas, Diretora do Museu Théo Brandão de Antropologia e Folclore da Universidade Federal de Alagoas. 


\section{Resumo}

Neste artigo, procuro contextualizar observações sobre as coreografias desenvolvidas por mim e por outros coreógrafos nos blocos afro carnavalescos Bankoma, Ilê Aiyê, Malê Debalê e Olodum, cheias de significados e de movimentos, aplicando meus próprios conhecimentos, assimilados durante o doutorado no Programa de Pós-Graduação em Artes Cênicas, da Universidade Federal da Bahia, bem como conteúdos aprendidos em Dança Moderna e Danças Africanas, enquanto dançarina e aluna do professor Clyde Wesley Morgan e do coreógrafo Buly Soukol, do Balé La Linguér, Senegal.

Palavras-chave: Blocos afro, Coreografia, Estética negra.

\section{Abstract}

In this article, I try to contextualize observations about the choreographies developed by other choreographers and myself in the Afro-Carnival groups Bankoma, llê Aiyê, Malê Debalê, and Olodum, full of meanings and movements, applying my own knowledge assimilated during the $\mathrm{PhD}$ Program in Performing Arts from Universidade Federal da Bahia, as well as content learned in Modern Dance and African Dances as a dancer and student of Professor Clyde Wesley Morgan and choreographer Buly Soukol, from Balé La Linguér, Senegal.

Keywords: Afro groups, Choreography, Black esthetics.

\section{Resumen}

En este artículo trato de contextualizar los comentarios sobre las coreografías desarrolladas por mí y por otros coreógrafos en los blocos afro de carnaval: Bankoma, Ile Aiye, Hombre Debalê y Olodum; coreografías de muchos significados y movimientos, aplicando mis conocimientos asimilados durante el doctorado en el Programa de PósGraduação em Artes Cênicas, de la Universidad Federal da Bahia, así como los contenidos en danza moderna y danza africana aprendidos como bailarina y estudiante del profesor Clyde Wesley Morgan y del coreógrafo Buly Soukol, Ballet la Linguér, Senegal.

Palabras clave: Blocos afro, Coreografía, Estética negra. 
Desde a adolescência, as artes fazem parte da minha vida. Eu arriscava cantar em rezas para Santo Antônio, nas aulas de canto do coral do ginásio João Florêncio Gomes, e também gostava de dançar merengue e twist, nas festinhas do bairro onde morava.

Foi no segundo grau, como aluna do curso técnico de Administração, no Colégio Estadual M. A. Teixeira de Freitas, no bairro de Nazaré, Salvador, onde formalizei meu interesse pelas Artes, nas aulas de teatro e de filosofia, com os professores Reinaldo e Ricardo Líper. Iniciei minha carreira de dançarina profissional, neste período, participando do grupo para-folclórico Olodumaré, por quatro anos, dançando em vários palcos de países europeus.

Foi dançando em grupos amadores e profissionais que aprendi muitas coisas sobre as culturas negro-brasileira e negro-africana, com destaque para o Grupo de Dança Contemporânea da Universidade Federal da Bahia, sob a direção do coreógrafo afro-americano Clyde Wesley Morgan. Entre as lembranças dançantes da minha juventude, o carnaval ocupa um lugar privilegiado em minha história de vida. Assim, a busca pela criação artística e pela transmissão de saberes, envolvendo corpo, dança, memória, ancestralidade e oralidade, fizeram que eu desenvolvesse um projeto de pesquisa, no doutorado, derivado de aspectos étnicos dos blocos afro: Ilê Aiyê, Olodum, Malê Debalê e Bankoma, que constituem uma das mais importantes expressões da cultura afro-brasileira presente na Bahia.

Até hoje, estou do lado de dentro desses objetos de pesquisa e, entre as fontes utilizadas, houve um campo principal, no qual conduzi minha etnografia sobre as coreografias desenvolvidas e ali contextualizadas, por meio da perspectiva da etnocenologia, com as minhas alunas do bloco afro Bankoma, no período de 2006 a 2008, coreografias que foram enriquecidas pela música percussiva, pelos adereços de mãos e de cabeça, e pelos figurinos desse bloco.

Partindo da ótica de Pradier (1997, p. 9), a etnocenologia traz para as artes cênicas uma abordagem pluricultural, proporcionando entendimentos sobre o corpo que se expressa, espetacularmente, pelas suas várias experiências e memórias coletivas.

Assim, sob a ótica da etnocenologia, aponto que a espetacularidade das danças negras dos blocos afro pesquisados não é um sistema codificado de danças ocidentais, como observamos nas técnicas de dança norte-americanas 
e europeias (balé, dança moderna, dança expressionista alemã, jazz, entre outras). Nos processos de criação e nas minhas aulas foram considerados alguns princípios básicos da cultura negra, por exemplo, atuar sempre em comunhão com os elementos do sagrado, sem estereotipar ou fingir que se está em transe, pois, para aqueles(as) jovens, o candomblé é a ligação com a ancestralidade.

Essas associações culturais carnavalescas, popularmente conhecidas como blocos afro, constituem uma das mais importantes expressões da cultura afro-brasileira presente na Bahia. Desde a fundação, sob o comando dos tambores, os moradores dos bairros, os foliões e turistas, cantam e dançam os seus protestos, suas alegrias, suas homenagens aos antepassados, aos seus heróis, sobretudo, ao continente africano - terra mater - a casa de origem da diáspora negra, reatualizando e recriando a memória ancestral.

Na perspectiva "de dentro" e como estudiosa dessas práticas, na cidade de Salvador, Bahia, posso falar com o valor de pertencimento sobre os processos de ações sociopolíticas e culturais (criações artísticas, formações profissionais, construções de identidades), que esses blocos desenvolvem nos seus bairros de origem: o llê Aiyê, no Curuzu; o Olodum, no Pelourinho; o Malê Debalê, em Itapuã; e o Bankoma, em Portão. As ações desses blocos afro antecedem a Lei 10.639, de 9 de janeiro de 2003, modificada para a Lei $11.645,{ }^{1}$ de 10 de março de 2008, passando a vigorar com a seguinte redação:

Art. 26-A - Nos estabelecimentos de ensino fundamental e de ensino médio, públicos e privados, torna-se obrigatório o estudo da história e cultura afro-brasileira e indígena.

$\S 1^{\circ} \mathrm{O}$ conteúdo programático a que se refere este artigo incluirá diversos aspectos da história e da cultura que caracterizam a formação da população brasileira, a partir desses dois grupos étnicos, tais como o estudo da história da África e dos africanos, a luta dos negros e dos povos indígenas no Brasil, a cultura negra e indígena brasileira e o negro e o índio na formação da sociedade nacional, resgatando as suas contribuições nas áreas social, econômica e política, pertinentes à história do Brasil.

1. Essa Lei é um possível elemento de combate ao preconceito e à discriminação étnico e racial a partir da escola nas questões negras e indígenas. 
$\S 2^{\circ}$ Os conteúdos referentes à história e cultura afro-brasileira e dos povos indígenas brasileiros serão ministrados no âmbito de todo o currículo escolar, em especial nas áreas de educação artística e de literatura e história brasileiras. (BRASIL, 2008, s/p)

É pertinente enfatizar a importância dos processos históricos que culminaram na aprovação da referida Lei, como o Motim do Maneta (1711), a Revolta do Terço Velho (1728), a Revolta de Búzios ou Conjuração Baiana (1798) e a Revolta dos Malês (1835). De acordo com Cunha Jr. (2001, p. 15), esses processos históricos não devem ser omitidos, pois tal estudo "facilita uma visão mais igualitária da História da humanidade

Segundo os ensinamentos de Kabengele Munanga (1999), nenhuma lei, em qualquer cultura, é capaz de destruir inteiramente atitudes preconceituosas. No entanto, acredito que a Lei 11.645/2008 (BRASIL, 2008) contribui para a construção da identidade étnico-racial, na formação dos educadores e na educação, estimulando os questionamentos e a desconstrução "dos mitos da superioridade e inferioridade entre grupos humanos que foram introjetados neles pela cultura racista na qual foram socializados" (MUNANGA, 1999, p. 17).

Para Oliveira (2013, p. 29), "a identidade é uma fonte de sentido de experiência". Não existe uma nação, um país ou uma pessoa sem nome. Isso já demonstra a diferença. Identidade não é uma descoberta, é também a construção do conhecimento de si, enquanto indivíduo. A identidade não existe sem a presença do outro. É uma categoria de definição e de identificação, ou seja, é a maneira como nos vemos.

Quando utilizo o termo identidade, compreendo a dimensão do termo e faço a opção por seu sentido na cultura afro-brasileira: "a identidade cultural de qualquer povo corresponde idealmente à presença simultânea de três componentes: o histórico, o linguístico e o psicológico" (MUNANGA, 1999, p. 46).

$\mathrm{Na}$ cidade de Salvador, tivemos a minicomunidade Oba Biyí que, durante os seus dez anos de existência (1976-1986), foi a primeira experiência de educação pluricultural no Brasil, sob a iniciativa do Alapini Mestre Didi - Deoscóredes Maximiliano dos Santos - criada no âmbito do llê Axé Opô Afonjá, localizado no bairro de São Gonçalo do Retiro. Apoiando essa iniciativa, está a venerável lyá Oba Biyí pela "fundadora do llê Axé Opô Afonjá". Atualmente, nesse mesmo espaço religioso, foi criada a Escola Eugênia Anna dos Santos. 
Outro espaço significativo de educação pluricultural é a Escola Mãe Hilda, fundada em 1988, pela lyalorisà Mãe Hilda Jitolú, e iniciada na sua comunidade-terreiro, na ladeira do Curuzu, bairro da Liberdade. Atualmente, essa escola está localizada na sede do bloco afro llê Aiyê, na mesma rua. Em ambas as escolas mencionadas, seus discentes, independente de qualquer credo religioso, estudam e aprendem com base na tradição africano-brasileira e iorubana.

Essas escolas e outras ações socioeducativas dos blocos afro pesquisados subsidiam os professores, as professoras e demais educadores e educadoras da rede de ensino formal e informal para pôr em prática as orientações emanadas dos Parâmetros Curriculares Nacionais. As sabedorias dos praticantes e das praticantes também foram incorporadas à elaboração deste artigo, não separando seus cotidianos ritualísticos e educacionais, condições herdadas, sobretudo, das etnias africanas, constituindo, assim, as matrizes estéticas negro-africanas/brasileiras, essenciais à compreensão da minha análise, prioritariamente, estético-artística.

Os estudos sobre a etnocenologia, realizados por Armindo Bião et al. (2001), facilitaram minha compreensão sobre a espetacularidade. Assim, ele explica: "Espetacularidade é a categoria dos jogos sociais onde o aspecto ritual ultrapassa a rotina: são os rituais religiosos, as competições esportivas, os desfiles e comícios, as grandes festas" (2001 p. 163-164). Essa reflexão corrobora a minha constatação de que essas práticas negras acontecem nesses blocos afro, de maneira natural e simples, entrelaçando-se, e, segundo Martins (2008, p. 38), estão intrinsecamente conectadas a todo processo religioso, que se entrelaça numa "unidade dinâmica", equilibrada e harmoniosa, do "corpo físico, emocional, espiritual e intelectual", contextualizado também pelo antropólogo norte-americano Thompson como "filosofia holística".

Outros artistas brasileiros também contribuíram para as nossas construções identitárias latino-americanas, cujas obras artísticas e ações contestavam as "velhas formas artísticas", orientadas pela estética europeia que predominava na arte e na literatura brasileira, em séculos passados. Entre aqueles e aquelas estão Mário de Andrade, Anita Malfatti e o maestro Heitor Villa-Lobos, cujas ações ecoaram em vários espaços e cujas práticas produziram frutos, com destaque para a Semana de Arte Moderna, realizada no Teatro Municipal de São Paulo, entre os dias 13 e 18 de fevereiro de 1922. 
No ethos educacional, Villa-Lobos lutou para que as suas composições fizessem parte da vida e da escola brasileira e dos bailados, a exemplo de: Caixinha de boas festas, Pedra bonita, Uirapuru, entre outras composições, como eu apresento em minha pesquisa sobre a Dança afro, em Salvador/BA (OLIVEIRA, 1991, p. 23).

Ressalto, também, as volumosas obras completas de Mário de Andrade sobre o movimento modernista, envolvendo a música brasileira, as artes plásticas do Brasil e os estudos de danças brasileiras, publicados sob o título de Danças dramáticas do Brasil (ANDRADE, 1982). Embora a Semana da Arte Moderna não tenha se convertido no fato mais importante da cultura brasileira, pois, até então, somente as criações originadas do continente europeu eram consideradas arte, fez que se instaurassem experimentações e pesquisas em torno da fundação de uma arte nacional e de sua própria estética. Nesse processo, não há registro de que a dança tenha sido apresentada e/ ou contextualizada.

Na explicação de Pereira (2003, p. 91), "a primeira escola oficial de dança foi fundada em 1927, no Rio de Janeiro", e outra em 1932, na cidade de São Paulo, por Chinita Ullman, que trouxe a dança moderna europeia, com enfoque na dança expressionista alemã, muito embora a dança sempre estivesse presente em várias partes do Brasil.

A trama provocada pela Semana de Arte Moderna adentrou as escolas, provocando uma nova forma de se ensinar música e pintura, criando, assim, um novo paradigma na educação artística. Lembro-me dessas influências, principalmente, nas aulas de canto orfeônico, nas quais aprendi a cantar os hinos e outras músicas, com temas folclóricos brasileiros. Entre as décadas de 1930 e de 1940, destaco duas entidades que foram de importância fundamental nessa questão étnico-racial: a Frente Negra Brasileira, criada na década de 1930 e o Teatro Experimental do Negro (TEN), fundado na cidade do Rio de Janeiro, em 1944, tendo como idealizador o artista visual, ator, senador e professor, Abdias do Nascimento.

Essas entidades estimularam o entendimento de ser negro e negra e de sermos respeitados e respeitadas, como seres humanos e todo o nosso legado, pela arte, pela educação e cultura brasileira. OTEN teve várias atividades, no Rio de Janeiro e em São Paulo, influenciando anos depois a comunidade 
negra baiana, com seus concursos de rainha e peças teatrais. Na opinião de Macedo (2006, p. 29), foi no "período de 26 de agosto a 04 de setembro de 1950, [que] o Distrito Federal abrigou o I Congresso do Negro Brasileiro," tendo entre outros palestrantes a ativista, coreógrafa e antropóloga afro-americana, Katherine Dunham.

Nessa perspectiva, o TEN promoveu uma série de eventos, tendo a colaboração da dançarina e coreógrafa afro-brasileira, Mercedes Baptista, com o objetivo de desenvolver um intercâmbio entre as culturas norte-americana e brasileira (Figura 1). Em uma das suas aulas de dança, "Miss Dunham solicita aos presentes que improvisassem mostrando as suas habilidades, de forma que Mercedes Baptista se destaca, embarcando para os Estados Unidos" (SILVA JR., 2007).

Figura 1 - A coreógrafa Mercedes Baptista, em apresentação de dança, na cidade do Rio de Janeiro

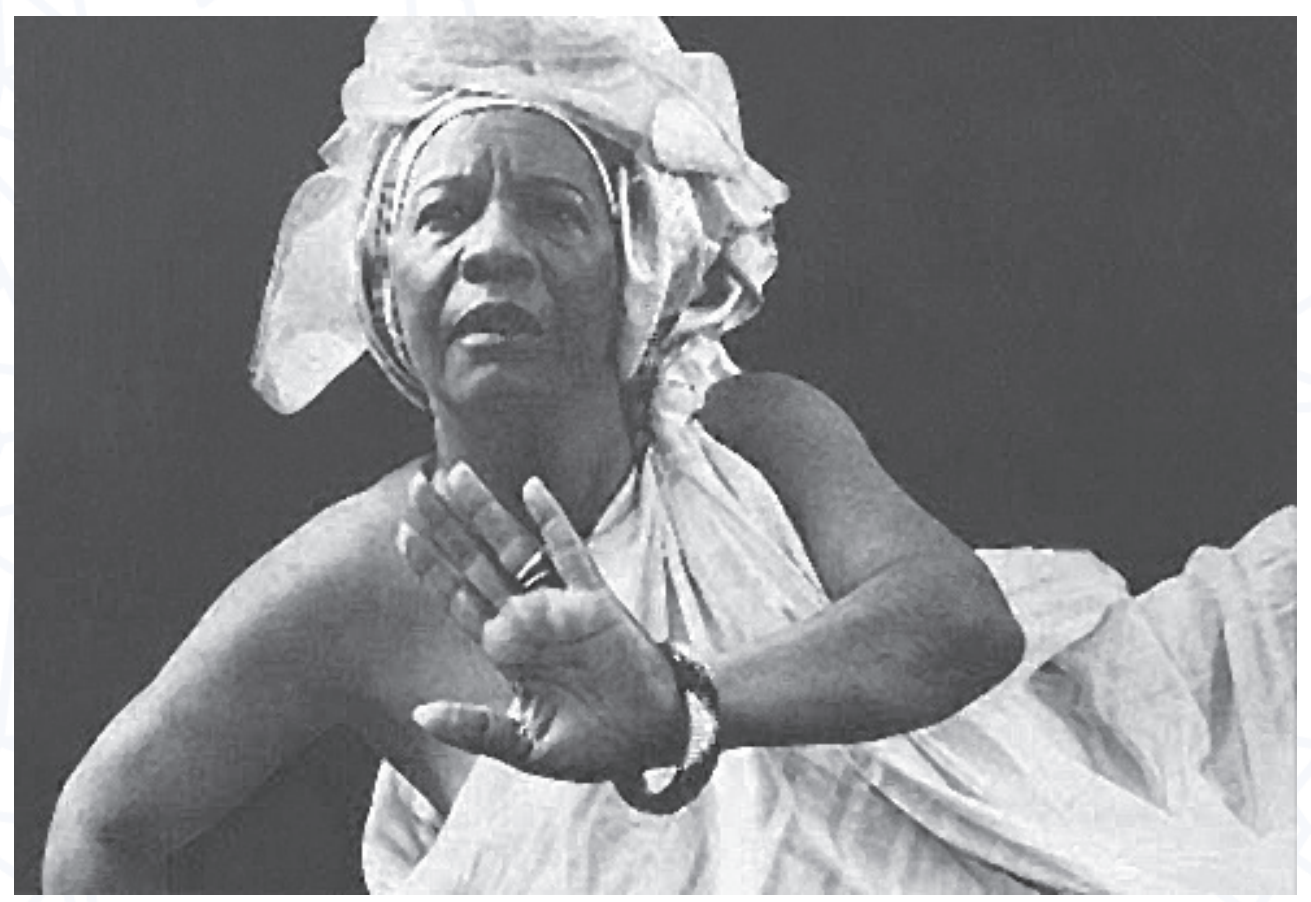

Fonte: Melo (2014)

Mercedes Baptista, ao retornar para o Brasil, resolve fazer o mesmo que Miss Dunham realizou nos Estados Unidos, ou seja, ela criou o Balé Afro-brasileiro, e, na visão de Oliveira, fica conhecida como a "mãe do balé afro", criando as coreografias culto a Yemanjá, Lavagem do Bonfim e Cafezal, com a colaboração do babalorixá baiano - Joãozinho da Gomeia, realizando várias apresentações pelo Brasil. 


\section{Nadir Nóbrega Oliveira}

Se, nos dias atuais, ainda é difícil para o(a) dançarino(a) negro(a) destacarem-se e sobreviverem dignamente, sendo remunerados(as) pelo seu trabalho profissional em dança, e sem os estereótipos estabelecidos pelas imposições mercadológicas, imaginem na década de 1940! As aulas de Mercedes Baptista, na Escola de Dança, situada na Avenida Copacabana, na cidade do Rio de Janeiro, foram eficientes para um determinado grupo de alunos e alunas, a exemplo de Marlene Silva, Isaura de Assis, Carlos Moraes e Domingos Campos, que se destacaram no mercado profissional internacional, e que tive a oportunidade de conhecer, quando ainda era dançarina do grupo Olodumaré.

Outro movimento significativo da radicalização da cultura brasileira foi o Tropicalismo, na década de 1960, quando o Brasil estava em pleno período da Ditadura Militar, contestando todas as formas de autoritarismo e tendo como principais líderes os artistas baianos Gilberto Gil e Caetano Veloso. Além das questões estéticas e literárias, o Tropicalismo revolucionou a cultura e a política brasileiras, como também mobilizou grande parte da população em suas canções inaugurais "Domingo no parque" (Gilberto Gil) e "Alegria, alegria" (Caetano Veloso). No Tropicalismo, as questões relacionadas com a diáspora africana estavam visíveis nas letras das músicas, no visual estético desses artistas, nos tipos de corte de cabelo, figurinos, nas atitudes e comportamento contestador. Naquela época, eles demonstravam saber que queriam participar da linguagem mundial, para nos fortalecer como povo e afirmar a nossa originalidade.

Está vivo, em minhas lembranças, o impacto causado, ao assistir pela televisão da minha vizinha de rua, Dona Edith, uma parteira, o cantor Gilberto Gil interpretando a canção "Domingo no parque", com os seus cabelos estilo black power. Segundo Caetano Veloso, citado por Almeida Jr. (2010, p. 19), o Tropicalismo "desestabilizou as hierarquias musicais, fundiu o erudito com o popular, desrespeitou as fronteiras entre as classes sociais e entre níveis de educação". Assim, pode ser considerado um movimento moderno brasileiro, que proporcionou um teatro performativo, uma nova forma de encenar com o corpo, questionando tradições cristãs, enfim, um movimento que contribuiu para estimular as criações de uma estética negra, um entendimento de corpo. A redescoberta do trabalho contextualizado no corpo, este que, segundo Jeudy (2002), pode ser visto como um "objeto de arte", e, de uma maneira 
intencional, a corporeidade "é uma representação objetiva" (2002, p. 57), a dança, como referência do corpo em movimento, é apresentada como uma "linguagem de passagem" (JEUDY, 2002, p. 68).

A leveza dos corpos quando se apresentam, dançando nesses blocos afro, ao som da percussão, contagia a ponto de provocar sensações e o desejo de dançar. Além disso, os movimentos desses corpos permitem fantasiar o desejo de nos aproximar deles e tocá-los. Nesses corpos negros que dançam, cantam e tocam, ficam nítidas as variações de movimentos corporais, orientadas pelas músicas percussivas. Corpos negros ondulados e dançantes, com os pés paralelos, deslizando na meia ponta e elevando os braços. Ouso afirmar que esses corpos negros, sujeitos da história, alimentam a renovação artística da dança e da música brasileira.

\section{Compreensão dos "pilares fundamentais e estruturais"}

Nessas criações artísticas estimulei meus estudantes, durante as aulas e oficinas que ministrei no bloco afro Bankoma, a captarem suas realidades, por meio da capacidade de observação, análise e imaginação. A partir de suas referências pessoais, condições socioculturais e de todas as impregnações que os cercavam, tornando-se visualmente contempláveis, graças às combinações dos movimentos corporais. Vários estímulos foram dados para gerarem coreografias, visando à projeção contemporânea de dança, tentando despertar também reflexões sobre o que é o continente africano e como era ensinado nas escolas formais onde eles estudavam. Para as montagens coreográficas, sem explicações prévias, alguns processos de pergunta-resposta com objetos do cotidiano não religioso, como guarda-chuva, bacia plástica e boneca, que tiveram como finalidade despertar, nas suas memórias, respostas ancestrais, eles foram o que Sánchez (2010) chama de "criadores-executantes," ou seja, as suas práticas dançantes tiveram sentidos, pois suas memórias foram acionadas. Esses processos artísticos e pedagógicos desenvolvidos por mim no bloco afro Bankoma, fortaleceram "outras instâncias de comportamentos humanos" (MUNANGA, 1999), enraizadas no passado ancestral, que apresento nas figuras 2 e 3 . 


\section{Nadir Nóbrega Oliveira}

Figura 2 - A dançarina Aline Santos, tendo como inspiração a orixá Yansã, divindade ancestral africana. Na sua composição coreográfica, em nível médio do espaço, enfatiza também o verbo "segurar" com uma colher de pau na sede do bloco afro Bankoma

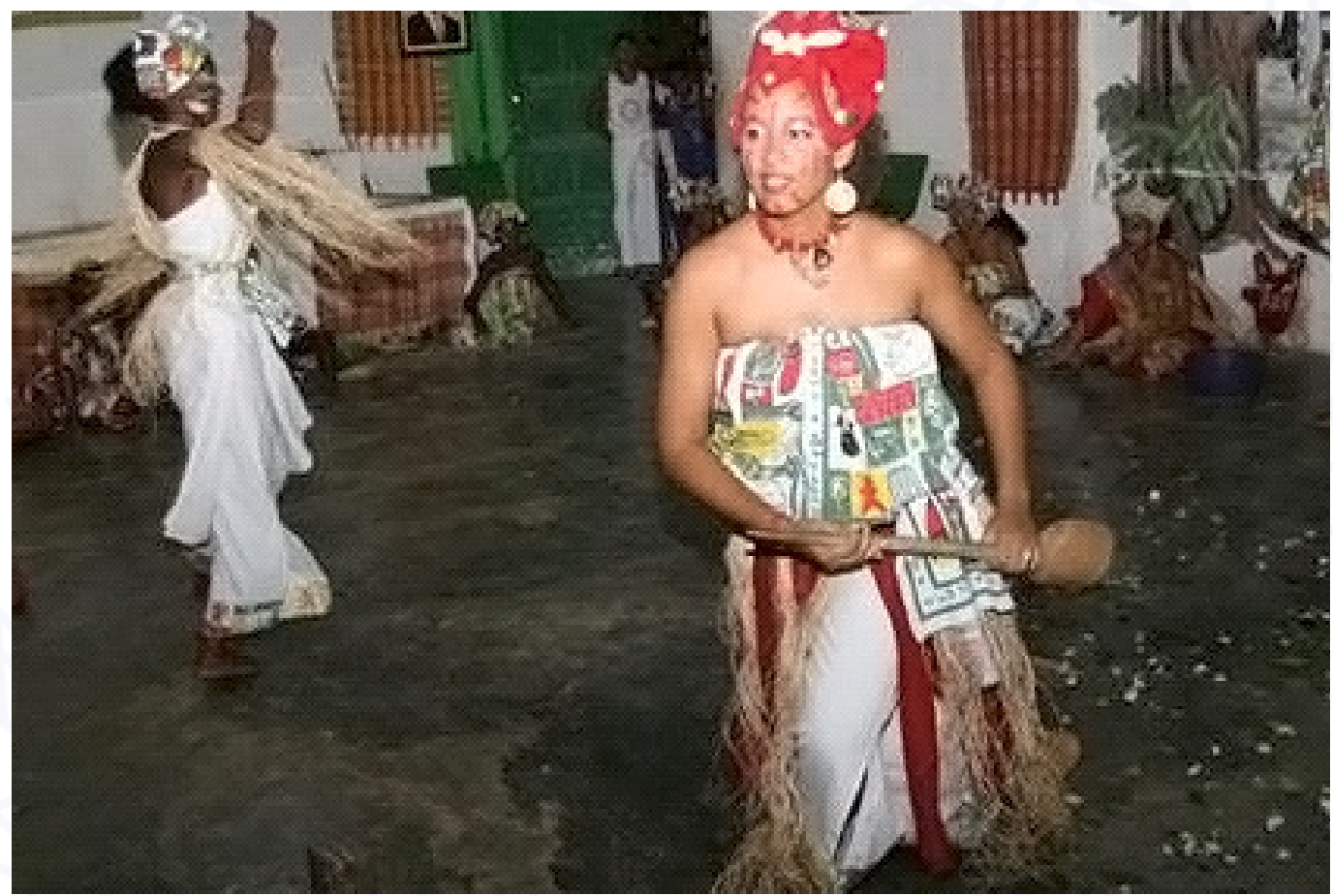

Foto: Nadir Nóbrega Oliveira(2008)

Figura 3 - Alunas da oficina de Técnica de Dança de Matriz Africana, durante a performance, com as fantasias do bloco afro Bankoma. Géssica Catarina, Daniela e Liane demonstram o nível médio do espaço, e movimentos dos braços que apontam para o chão

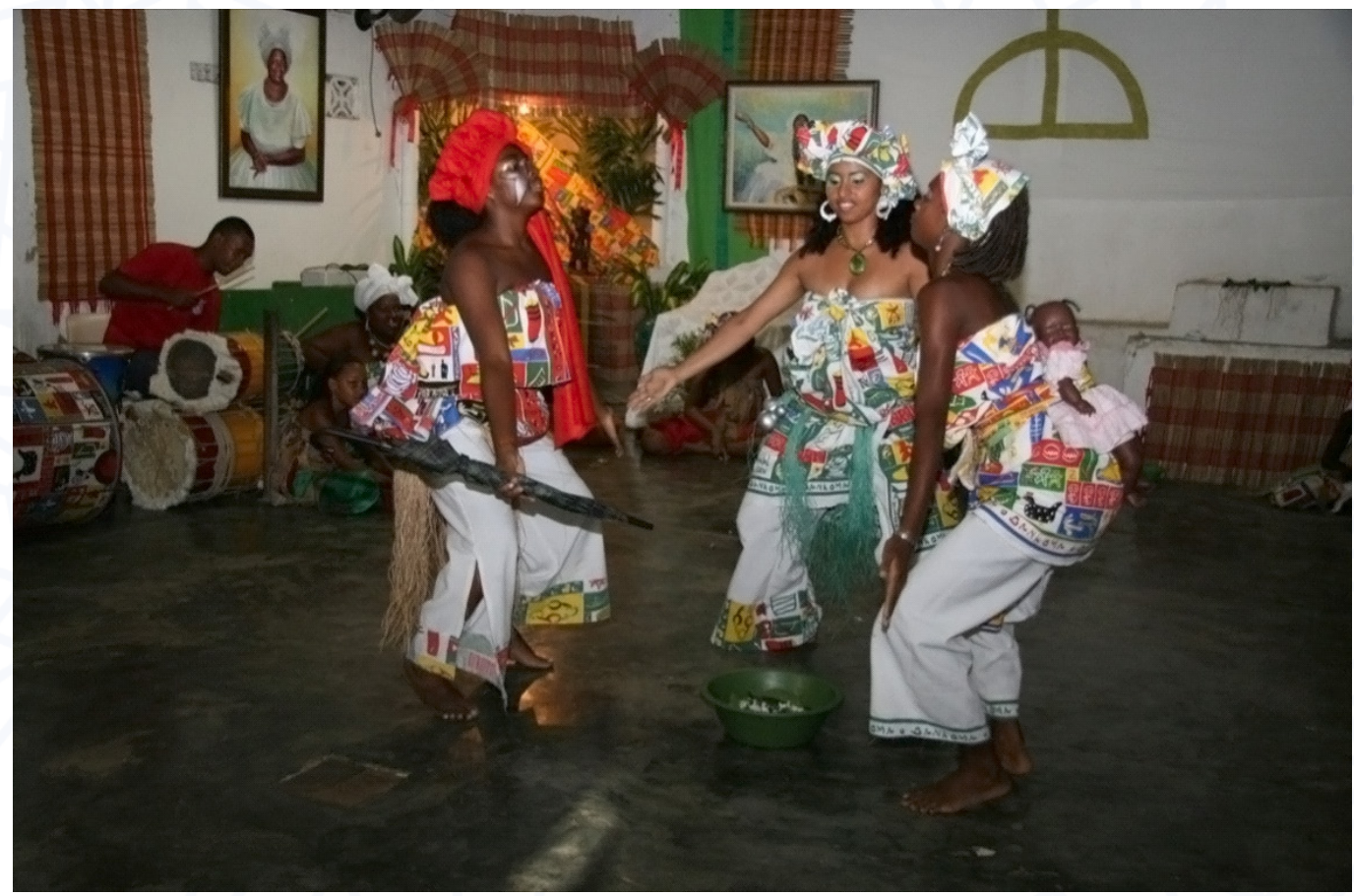

Foto: Nadir Nóbrega Oliveira (2008) 
Uma das minhas ex-alunas, Géssica Catarina, exemplifica esse corpo, ilustrando a memória épica e a sua história, expressando-se poeticamente:

O meu objeto é uma sombrinha que passa a ser um cajado, porque esse cajado é de Exu e os meus movimentos estão relacionados a ele. A sombrinha no começo do espetáculo vai aberta até a minha colega de dança que busca ela como se fosse um escravo levando a madame. (Géssica Catarina, 2008)

No livro A dança de Yemanjá Ogunté sob a perspectiva estética do corpo, de autoria da dançarina, professora e pesquisadora em dança, Suzana Martins (2008), encontrei estudos sobre determinados componentes estéticos das danças de matrizes negro-africanas, que são intitulados de "pilares fundamentais e estruturais", e que são visíveis, tanto em coreografias desses blocos afro, quanto nas danças sagradas do candomblé. Esses pilares, juntos, funcionam como "mola propulsora da estética negra" (MARTINS, 2008, p. 117); são eles: polirritmia ou múltiplos metros, policentrismo e holismo. Martins descreve a polirritmia, de acordo com os estudos de Asante (1985), e diz que a performance do corpo "utiliza diferentes ritmos para diferentes movimentos evoluindo de maneira integral” (MARTINS, 2008, p. 118).

A autora ressalta, ainda, que partes do corpo "cabeça e mãos podem executar movimentos vibratórios e, ao mesmo tempo, circulares, enquanto a pélvis contrai-se dobrando o ritmo e os pés marcando o metro do tempo" (Ibid., p. 118). O segundo pilar, o policentrismo, também estudado por Asante (1985), é contextualizado e definido por Martins "como moção, expandindo tempo e o espaço" (2008, p. 119). Esse pilar pode ser facilmente observado nos corpos, executando o samba ljexá e o samba reggae, que se locomovem no espaço, de maneira expandida, estimulados pelos toques das percussões. Ainda comenta Martins que a filosofia holística fundamenta o terceiro pilar, que tem "como uma das características a conexão entre as partes do corpo que se movimentam interagindo entre si" (Ibid., p. 120).

Em uma das sequências de movimentos em locomoção nesses blocos afro, os braços semiflexionados elevam-se de maneira revezada, enquanto uma perna é flexionada e elevada em oposto ao braço, com o tronco inclinado para frente e a cabeça virando para um lado e para o outro. Essas ações 
são coordenações motoras transmitidas oralmente e, aparentemente, de fácil execução, porém, como um "ser de dentro" desses blocos afro, vejo que essas coordenações motoras exigem determinadas habilidades corporais, pois a polirritmia, o policentrismo e o sentido holístico são componentes executados de forma sutil e, naturalmente, integrados aos movimentos dos corpos negros.

São corpos negros que dançam, diariamente, transitam pelas ladeiras, pelos becos, pelas comunidades e terreiros, pelos grupos de samba e também pelas escolas públicas e privadas, do ensino fundamental e médio. Assim:

As condições soteropolitanas de existência singular do corpo baiano se assemelham às realidades climáticas e à ambientação urbana, sua geografia e sua geopolítica, sem deixar de relacionar ainda aspectos psicológicos e místicos. Todo o contexto de entorno de gestação desta sociedade, no grupo social e no imaginário coletivizado das práticas sociais, deve ser considerado na afirmação destes corpos fácies, leves, gingados, não como causa, mas como um conjunto de engrenagens importantes na análise do comportamento encantado deste fenômeno corporal. (BARBOSA, 2006, p. 21 apud SERRANO, 2010, p. 138)

As referências culturais dos seus cotidianos, as festas, o carnaval, as religiões estão imbricados em seus corpos, criando, assim, uma cultura urbana e popular nesta cidade, que é chamada "terra da felicidade", onde "todo mundo é de Oxum". Essas danças fazem parte das tradições étnico-culturais brasileiras e podem ser apresentadas nas quadras dos blocos afro, nas praças, nos palcos convencionais, nos terreiros ou nos desfiles de carnaval, proporcionando ao folião e ao espectador a compreensão de fatos do mundo que vão além do entretenimento. São narrativas históricas de um país africano imaginário ou de algum lugar da diáspora africana.

Nos blocos afro, as danças são, geralmente, apresentadas nos palcos e nas praças, cujo elenco, na maioria das vezes, está com os pés descalços, porém, durante o carnaval ou em outros eventos de rua, os dançarinos e as dançarinas usam alpercatas de couro sintético, sapatilhas confortáveis e sapatos esportivos. As danças apresentadas por esses blocos afro fazem parte do que é convencionado como dança afro-brasileira ou dança afro-baiana, apresentando elementos técnicos/estéticos e corporais próprios, os quais destaco: 
- Pés planos em contato direto com o chão, joelhos e pernas semiflexionados, em posições paralelas;

- Pés dobrados e deslizando no espaço, com dedos em meia ponta;

- Braços semiflexionados, balançando para frente e para trás, e elevando-se de maneira alternada;

- Movimentos executados, geralmente, obedecendo aos ritmos percussivos estabelecidos pelos blocos: samba ljexá, Aguéré de Òxòssi, samba reggae, entre outros;

- Coluna vertebral nos planos vertical e sagital (com flexão e extensão para a frente e para os lados), podendo ser o que Martins (2008) intitula getdown, visível nas danças de matrizes afro-brasileiras;

- Movimentos de requebrados com quadris relaxados e reagindo aos sons percutidos em contratempo com as batidas dos pés no chão;

- Movimentos assimétricos e circulares com paradas (pausas, expandindo o tempo e o espaço, contrastando com o ritmo ou pulsação da música);

- Bacia óssea em movimentos de retroversão, que no senso comum são conhecidos como "bacia desencaixada".

É interessante notar que na discussão sobre a estética negra, esses blocos afro, desde as suas fundações, apresentam a música imbricada a um conjunto de ações que estão também inseridas nas danças; no modo de pentear e arrumar os cabelos; na criação dos figurinos e dos adereços, materializando a ancestralidade das etnias afro-brasileiras, pois, assim como na África, a dança e a música são a alma desses blocos afro carnavalescos. Nesse universo multicultural, esses blocos afro se apresentam de maneira inter e transdisciplinar, são multidimensionais e provocam impactos em muitas áreas do conhecimento humano.

Portanto, acredito que os fundamentos estéticos da dança e da música desses blocos, em que o corpo expressa desejos, devaneios e utopias históricas, são diferenciados de outras modalidades de dança e música, por exemplo, a dança e a música contemporâneas. Na afirmativa de Pradier (1997, p. 13), o corpo é o "lugar da encarnação do imaginário". São corpos captadores, apreendedores, transformadores e (re)criadores de uma determinada estética, interconectados, sujeitos das suas histórias e cadenciados pelo ritmo do samba ijexá e do samba reggae. 
Durante os momentos dos desfiles dos blocos nas ruas, os dançarinos e as dançarinas ficam impossibilitados(as) de atuar no chão. Mas, durante minhas aulas de técnica de dança de matriz africana, desenvolvidas no bloco afro Bankoma, os exercícios técnicos corporais e musicais estimularam os/ as discentes a também usarem o nível baixo. E, nas apresentações finais das oficinas, todos conseguiram realizar "proezas" artísticas, nos diversos níveis.

\section{Conclusão}

Ao tentarmos definir a estética negra em dança, não podemos padronizá-las segundo códigos preestabelecidos, como se observa na dança moderna ou no balé clássico, por exemplo. Nesse sentido, o contexto sociocultural e também religioso, tendo em vista que os blocos afro da Bahia, em sua maioria, estão conectados ao candomblé, apresentam uma gama de significados de movimentos que não se enquadra em nenhuma categoria contemporânea de dança. Ao contrário, a estética negra em dança evolui de acordo com seus próprios princípios técnicos/criativos, que têm outra finalidade, trazem suas experiências culturais cotidianas e seu jeito próprio de dançar, seja no coletivo, seja de forma individual. Os "pilares fundamentais e estruturais" - polirritmia ou múltiplos metros, policentrismo e holismo - apontados por Martins, são realmente visíveis e funcionam como "mola propulsora da estética negra" (MARTINS, 2008), sem, contudo, padronizá-la em códigos de movimento.

Enfim, as danças dos blocos afro llê Aiyê, Olodum, Malê Debalê e Bankoma apresentam elementos técnicos/criativos/estéticos, que estão imbricados a outros elementos multiculturais. Essas coreografias possuem importância fundamental para serem incluídas na história da dança mundial, justamente pela espetacularidade das matrizes afro-brasileiras que as compõem, no cenário carnavalesco da cidade de Salvador.

\section{Referências bibliográficas}

ALMEIDA JR., A. F. A contracultura e a política que o llê Aiyê inaugura: relações de poder na contemporaneidade. 2010. 178 f. Tese (Doutorado em Cultura e Sociedade) - Faculdade de Comunicação, Universidade Federal da Bahia, Salvador, 2010. 
ANDRADE, M. de. Danças dramáticas do Brasil. Belo Horizonte: Itatiaia, 1982.

ASANTE, K. W. Commonalities in african dance: an aesthetic foundation. In:

ASANTE, M. K.; ASANTE, K. W. African culture: the rhythms of unity. New Haven:

Greenwood, 1985.

BRASIL. Lei no 11.645, de 10 de março de 2008. Altera a Lei no 9.394, de 20 de dezembro de 1996, modificada pela Lei no 10.639, de 9 de janeiro de 2003, que estabelece as diretrizes e bases da educação nacional, para incluir no currículo oficial da rede de ensino a obrigatoriedade da temática "História e Cultura Afro-Brasileira e Indígena". Diário Oficial da União. Poder Legislativo. Brasília, DF, 11 mar. 2008. Seção 1, p. 1. Disponível em: <https://goo.gl/mmjVqR>. Acesso em: 17 jul. 2016.

BIÃO, A. Etnocenologia, uma introdução. In: GREINER, C.; BIÃO, A. (org.). Etnocenologia: textos selecionados. São Paulo: Annablume, 1999. p. 15-22.

BIÃO, A. et al. (org.). Temas em contemporaneidade, imaginário e teatralidade. São Paulo: Annablume, 2001.

CUNHA JR., H. A História Africana e os elementos básicos para seu ensino. In: LIMA,

I. C.; ROMÃO, J. (org.). Negros e currículo. Florianópolis: Atilènde, 2001. (Série Pensamento Negro em Educação, Vol. 2).

JEUDY, H.-P. O corpo como objeto de arte. São Paulo: Estação Liberdade, 2002. LABAN, R. Domínio do movimento. São Paulo: Summus, 1978.

LUZ, N. C. P. Bahia a Roma negra: estratégias comunitárias e educação pluricultural. In: CONGRESSO BRASILEIRO DE CIÊNCIAS DA COMUNICAÇÃO INTERCOM, 25., 2002, Salvador. Anais... Salvador: Sociedade Brasileira de Estudos Interdisciplinares da Comunicação, set. 2002. p. 1-18.

MACEDO, M. J. Abdias do Nascimento: a trajetória de um negro revoltado (1913-1968). 2006. 285 f. Dissertação (Mestrado em Sociologia) - Faculdade de Filosofia Letras e Ciências Humanas, Universidade de São Paulo, São Paulo, 2006. MARTINS, S. A dança de Yemanjá Ogunté sob a perspectiva estética do corpo. Salvador: EGBA, 2008.

MELO, G. Divina, tu és, Mercedes Baptista! Salgueiro, Rio de Janeiro, 18 ago. 2014. Disponível em: <http://bit.ly/2vCSRtG>. Acesso em: 27 jun. 2015.

MUNANGA, K. Rediscutindo a mestiçagem no Brasil: Identidade nacional versus identidade negra. Petrópolis: Vozes, 1999. (Coleção Identidade Brasileira).

OLIVEIRA, N. N. Dança afro-sincretismo de movimentos. Salvador: Ufba, 1991.

Agô Alafiju, Odara! A presença de Clyde Wesley Morgan na Escola de Dança da UFBA, de 1971 a 1978. 2006. 317 f. Dissertação (Mestrado em Artes Cênicas) - Programa de Pós-Graduação em Artes Cênicas, Universidade Federal da Bahia, Salvador, 2006.

Sou negona, sim senhora! Um olhar nas práticas espetaculares dos blocos afro llê Aiyê, Olodum, Malê Debalê e Bankoma no carnaval soteropolitano. 
2013. 254 f. Tese (Doutorado em Artes Cênicas) - Programa de Pós-Graduação em Artes Cênicas, Universidade Federal da Bahia, Salvador, 2013.

PEREIRA, R. A formação do balé brasileiro: nacionalismo e estilização. Rio de Janeiro: FGV, 2003.

PRADIER, J.-M. Etnocenologia: a carne do espírito. Tradução Armindo Bião. Revista Repertório: Teatro e Dança, Salvador, n. 1, p. 9-21, 1997.

SÁNCHEZ, L. M. M. A dramaturgia da memória no teatro-dança. São Paulo: Perspectiva, 2010.

SERRANO, L. S. Corpografias: uma leitura corporal dos intérpretes-criadores do grupo Dimenti. 2010. 215 f. Tese (Doutorado em Artes Cênicas) - Programa de Pós-Graduação em Artes Cênicas, Universidade Federal da Bahia, Salvador, 2010. SILVA JR., P. M. Mercedes Baptista: a criação da identidade negra na dança. Brasília, DF: Fundação Cultural Palmares, 2007.

Recebido em 26/06/2017

Aprovado em 26/06/2017

Publicado em 05/09/2017 